\title{
Factors affecting actual weaning weight, preweaning average daily gain and relative growth rate in Asturiana de los Valles beef cattle breed
}

\begin{abstract}
In this paper we analyse the major environmental and genetic factors affecting actual weaning weight (WW), preweaning average daily gain (ADG) and relative growth rate (RGR) in a representative sample of field data of Asturiana de los Valles beef cattle breed. Major environmental factors affect preweaning growth performance of Asturiana de los Valles calves in the direction usually found in the literature. However RGR seems to be selfcorrected for sex of calf and calving number. Heritabilities for the direct and maternal genetic effects were 0.67 and $0.29,0.51$ and 0.31 and 0.18 and 0.12 respectively for WW, ADG and RGR. The estimates of genetic parameters affecting RGR are more realistic than those estimated for the WW and ADG. Selection for RGR would lead to obtain higher growth rates and lower birth weights. RGR could be an interesting selection criterion in beef cattle improvement programs.
\end{abstract}

Key Words: environmental factors, heritability, maternal effects

\section{Zusammenfassung}

Titel der Arbeit: Einfluss von Umwelt- und genetischen Faktoren auf das Gewicht beim Absetzen, die durchschnittliche Tageszunahme vor dem Absetzen sowie die relative Wachstumsrate bei Kälbern der Fleischrindrasse „Asturiana de los Valles

Es wurden die wichtigsten Umwelt- und genetischen Faktoren untersucht, welche das Gewicht beim Absetzen, die durchschnittliche Tageszunahme vor dem Absetzen sowie die relative Wachstumsrate von Kälbern der Asturiana de los Valles Fleischrinderrasse beeinflussen. Es konnte gezeigt werden, dass die wichtigsten Umweltfaktoren die Wachstumsleistung der Kälber vor dem Absetzen beeinflussen, wie dies auch in der Literatur beschrieben wird. Die relative Wachstumsrate scheint jedoch bezüglich des Geschlechtes der Kälber und der Abkalbungszahl selbstkorrigierend zu sein. Die Heritabilitätsschätzwerte für die direkten bzw. mütterlichen Effekte des Kälbergewichtes beim Absetzen, die Tageszunahme vor dem Absetzen und die relative Wachstumsrate der Kälber betrugen 0,67, 0,29 und 0,51 beziehungsweise 0,31, 0,18 und 0,12. Die genetischen Schätzwerte, die die relative Wachstumsrate beeinflussen, waren ausgeprägter als jene, die für das Absetzgewicht und die Tageszunahme beobachtet wurden. Eine Selektion in Bezug auf die relative Wachstumsrate würde zu einer Verbesserung dieses Merkmals und zu einem niedrigeren Geburtsgewicht führen. Damit könnte die relative Wachstumsrate ein interessantes Selektionsmerkmal bei Zuchtprogrammen von Fleischrindrassen darstellen.

Schlüsselwörter: Umweltfaktoren, Heritabilität, mütterlicher Effekt

\section{Introduction}

Since knowledge of factors affecting preweaning growth in beef calves is helpful in formulating management and selection decisions, preweaning growth traits are usually evaluated in most of the current improvement programs in beef cattle (SHI et al., 1993; GUTIÉRREZ et al., 1997). Weights at weaning give breeders useful information to test growth ability. Preweaning growth has usually been evaluated as average daily gain from 
birth to weaning using records at these ages. However, some authors have proposed to characterise the growth ability as a relative rate taking into account the average body mass (FITZHUGH and TAYLOR, 1971; AHUNU and MAKARECHIAN, 1987).

'Asturiana de los Valles' is a local Spanish beef cattle breed, exploited mostly in traditional valley-mountain grazing system in the north of Spain. Weaned calf is the major commercial product in the breed. Double muscled animals are frequent. There are evidences that muscular hypertrophy can affect growth performance (GOYACHE et al., 2002). The aim of this paper is to determine the importance of the main environmental and genetic factors influencing preweaning growth in the Asturiana de los Valles cattle, focusing on relative growth rates.

\section{Material and methods}

The Regional Government of Principado de Asturias, through the Asturiana de los Valles Breeders Association (ASEAVA), have implemented performance recording (CORECA database) based on nuclei grouping farms according to their proximity and their production system arising from small farm size (GOYACHE and GUTIERREZ, 2001; GOYACHE et al., 2002). We analysed 3,829 single calving records including weaning and birth weights and dates, sex of calf, calving number of the dam and degree of muscularity of dam and calf. Age at weaning of the available records ranged from 90 to 270 days. Degree of observable muscularity in dams and in calves at birth, was phenotypically assessed as 0 (poor muscular development), 1 (good muscular development) and 2 (excellent muscular development) by trained ASEAVA's classifiers (GOYACHE et al., 2002). This classification is expected to characterise in some extent the degree of expression of a possible subjacent muscular hypertrophy. Class 2 is expected to contain all the phenotypically double muscled animals in our database.

Three traits have been analysed in this paper: a) actual weaning weight (WW); b) preweaning average daily gain $(\mathrm{ADG})$, computed as $\mathrm{ADG}=(\mathrm{WW}-\mathrm{BW}) / \mathrm{AGE}$, being $\mathrm{BW}$ the actual birth weight and AGE the age of the calf at weaning, and c) relative growth rate (RGR), defined as average daily gain relative to body weight, was computed as RGR $=\log (\mathrm{WW} / \mathrm{BW}) / \mathrm{AGE}$, being log the natural logarithm (FITZHUGH and TAYLOR, 1971; AHUNU and MAKARECHIAN, 1987)

The statistical analysis was done with GLM Procedure of SAS (SAS, 1999). Sum of squares were estimated using Type III test. Least square means were computed and Duncan's multiple-range test was performed on all main-effect means affecting the three analysed traits. The model fitted to analyse preweaning growth traits included as fixed effects: management group by year of calving, calving month, calving number (6 levels: first calving, second calving, third calving, fourth calving, from 5 to 9 calvings and more than 9 calvings), calf sex, muscularity of calf; muscularity of dam (classified as described above) and age at weaning both as linear and quadratic covariate.

Genetic parameters affecting the three preweaning growth traits were analysed with Meyer's DFREML program (1991) under an animal model. The program has been restarted with different $a$ priori values of the genetic parameters to avoid confusion arising from the possible existence of local maxima. Structure of analysed data is shown in Table 1. Fitted model included five fixed effects: management group by year of calving as a comparison group, period of calving, calving number, sex of calf and age at weaning as both linear and quadratic covariates. The random effects included the 
additive genetic effect, the maternal genetic effect, the covariance between both direct and maternal genetic effects being its variance-covariance matrix proportional to the additive numerator relationship matrix, and the residual. Total heritability $\left(\mathrm{h}_{\mathrm{T}}^{2}\right)$ has been calculated with the formula $h_{T}^{2}=\left(\sigma^{2}{ }_{\mathrm{a}}+1.5 \sigma_{\mathrm{am}}+0.5 \sigma_{\mathrm{m}}^{2}\right) / \sigma^{2}($ DICKERSON, 1947), being $\sigma^{2}$ the phenotypic variance

Table 1

Structure of data used for the estimation of genetic parameters of three preweaning growth traits in Asturiana de los Valles beef cattle breed (Schätzung genetischer Parameter von drei Wachstumsmerkmalen vor dem Absetzen bei Asturiana de los Valles Fleischrindern)

\begin{tabular}{lc}
\hline Structure of data & \\
\hline Number of animals & 6,498 \\
Animals with record & 3,449 \\
Sires & 449 \\
Dams & 2,600 \\
Animals in model & 6,498 \\
Sires with record and offspring & 22 \\
Dams with record and offspring & 94 \\
Environmental effects & 111 \\
$\quad$ Nucleus-year & 2 \\
$\quad$ Calving season & 6 \\
$\quad$ Calving number & 2 \\
$\quad$ Calf sex & 1 \\
\hline \multicolumn{2}{c}{ Age at weaning (linear covariate) } \\
\hline
\end{tabular}

\section{Results}

Overall means and standard deviations of the preweaning growth traits were of $217.60 \pm$ $35.22 \mathrm{Kg}, 0.970 \pm 0.199 \mathrm{Kg} /$ day and $0.009241 \pm 0.001226$ points/day for WW, ADG and RGR, respectively. The average age at weaning was approximately 6 months (183.7 \pm 40.7 days). Results of the analysis of the environmental factors affecting our traits are shown in Table 2. Marked differences between traits were found. Coefficients of determination $\left(\mathrm{R}^{2}\right)$ of the fitted models were 0.563 for WW, 0.317 for ADG and 0.603 for RGR. Management group and age at weaning as a linear covariate influence significantly the three analysed traits. However, the other effects included in the models do not affect significantly all the traits. Month of calving and age at weaning as a quadratic covariate do not influence significantly WW; degree of muscularity of calf and dam do not influence significantly ADG and calving number and sex of calf do not affect RGR.

WW is largely dependent on the age at weaning that is, in turn, dependent on the month of birth of the calf, whereas ADG seems to be affected by the particular conditions of each season of calving. Calves born from January to April have lower growth rates (between 0.920 and $0.960 \mathrm{Kg}$ /day) while those born in the other months have significantly higher growth rates around $1 \mathrm{Kg} / \mathrm{day}$. The variation of RGR by month of birth is dependent on the variation of ADG (AHUNU and MAKARECHIAN, 1987). Calves born in the first part of the year obtain higher WW than the others. This growth pattern is affected by the traditional management of the breed. The average age at weaning in the former four months of the year is above the mean age at weaning reported in this study. The age at weaning between May and October is around 165 days. In November and December the mean age at weaning increases but always below the overall mean. Calves born in the first part of the year are weaned when they leave 
mountain pastures at 7 months of age. Calves born in spring or summer are weaned at 56 moths to be sold avoiding the extra-costs of wintering. Finally, calves born in the last months of the year are sold slightly older in the spring markets after a little grazing period in which the nursing ability of the cow increases, reaching higher WWs.

Table 2

Degrees of freedom, mean squares (MS), F-values and significance of phenotypic sources of variation affecting three preweaning growth traits in Asturiana de los Valles beef cattle breed (Freiheitsgrade, mittlere Abweichungsquadrate, F-Werte und Wichtung phänotypischer Beeinflussung von drei Wachstumsmerkmalen vor dem Absetzen bei Asturiana de los Valles Fleischrindern)

\begin{tabular}{|c|c|c|c|c|c|c|c|}
\hline & & \multicolumn{2}{|c|}{ Actual weaning weigh } & \multicolumn{2}{|c|}{ Average daily gain } & \multicolumn{2}{|c|}{ Relative growth rate } \\
\hline $\begin{array}{l}\text { Sources of } \\
\text { variation }\end{array}$ & d.f. & MS & $\mathrm{F}$ & MS & $\mathrm{F}$ & $\operatorname{MS}\left(\times 10^{-5}\right)$ & $\mathrm{F}$ \\
\hline Management group & 73 & 17936.40 & $14.46^{* * *}$ & 0.4779 & $12.07^{* * *}$ & 1.232 & $7.61^{* * *}$ \\
\hline Month of calving & 11 & 1665.73 & 1.34 & 0.0728 & $1.84^{*}$ & 0.591 & $3.65^{* * *}$ \\
\hline Calving number & 5 & 48880.24 & $39.41^{* * *}$ & 1.1532 & $29.13^{* * *}$ & 0.141 & 0.87 \\
\hline Sex of calf & 1 & 264745.69 & $213.47^{* * *}$ & 4.8936 & $123.59^{* * *}$ & 0.109 & 0.67 \\
\hline Muscularity of calf & 2 & 11618.25 & $9.37^{* * *}$ & 0.0486 & 1.23 & 5.72 & $35.36^{* * *}$ \\
\hline Muscularity of dam & 2 & 5743.67 & $4.63^{* * *}$ & 0.0500 & 1.26 & 0.578 & $3.57^{*}$ \\
\hline Age at weaning & & & & & & & \\
\hline Linear covariate & 1 & 2170996.01 & $1750.54^{* * *}$ & 12.6270 & $318.9^{* * *}$ & 572.441 & $3538.58^{* * *}$ \\
\hline Quadratic covariate & 1 & 2259.97 & 1.82 & 0.4385 & $11.08^{* * *}$ & 24.326 & $150.37^{* * *}$ \\
\hline error & 3732 & 1240.18 & & 0.03959 & & 0.162 & \\
\hline
\end{tabular}

$* \mathrm{P}<0.05 ; * * \mathrm{P}<0.01 ; * * * \mathrm{P}<0.001$

Table 3

Least squares means and standard errors (s.e.) three preweaning growth traits by the major sources of variation in Asturiana de los Valles beef cattle breed (Mittelwerte und Standardfehler der wichtigsten Einflussgrößen auf unterschiedliche Merkmale)

\begin{tabular}{|c|c|c|c|c|c|c|c|}
\hline & \multicolumn{7}{|c|}{$\begin{array}{l}\text { Actual weaning weight Average daily gain Relative growth rate } \\
(\mathrm{Kg})\end{array}$} \\
\hline & $\mathrm{N}$ & Mean & s.e. & Mean & s.e. & Mean $\left(\mathrm{x} 10^{-3}\right)$ & s.e. $\left(\mathrm{x} 10^{-5}\right)$ \\
\hline \multicolumn{8}{|l|}{ Sex of calf } \\
\hline Female & 1,921 & $209.45^{\mathrm{a}}$ & 1.41 & $0.939^{\mathrm{a}}$ & 0.008 & $9.25803^{\mathrm{a}}$ & 5.107 \\
\hline Male & 1,908 & $226.57^{\mathrm{b}}$ & 1.41 & $1.013^{\mathrm{b}}$ & 0.008 & $9.29275^{\mathrm{b}}$ & 5.076 \\
\hline \multicolumn{8}{|l|}{ Calving number } \\
\hline First & 595 & $202.25^{\mathrm{d}}$ & 1.77 & $0.897^{\mathrm{d}}$ & 0.010 & $9.18143^{\mathrm{a}}$ & 6.41 \\
\hline Second & 595 & $214.71^{c}$ & 1.78 & $0.963^{\mathrm{c}}$ & 0.010 & $9.32069^{\mathrm{a}}$ & 6.43 \\
\hline Third & 569 & $218.34^{\mathrm{b}}$ & 1.82 & $0.979^{b}$ & 0.010 & $9.29356^{\mathrm{a}}$ & 6.56 \\
\hline Fourth & 517 & $223.61^{\mathrm{ab}}$ & 1.90 & $1.006^{\mathrm{a}}$ & 0.011 & $9.30961^{\mathrm{a}}$ & 6.86 \\
\hline From 5 to 9 & 1,395 & $226.14^{\mathrm{a}}$ & 1.47 & $1.013^{\mathrm{a}}$ & 0.008 & $9.26492^{\mathrm{a}}$ & 5.3 \\
\hline More than 9 & 158 & $223.00^{\mathrm{a}}$ & 3.10 & $0.998 a^{b}$ & 0.018 & $9.28217^{\mathrm{a}}$ & 11.18 \\
\hline \multicolumn{8}{|l|}{ Muscularity of calf } \\
\hline Class 2 & 1,235 & $220.68^{\mathrm{a}}$ & 1.47 & $0.979^{\mathrm{ab}}$ & 0.008 & $9.04670^{\mathrm{b}}$ & 5.306 \\
\hline Class 1 & 641 & $218.74^{\mathrm{a}}$ & 1.83 & $0.981^{\mathrm{a}}$ & 0.010 & $9.29383^{\mathrm{a}}$ & 6.611 \\
\hline Class 0 & 1,953 & $214.60^{\mathrm{a}}$ & 1.47 & $0.968^{\mathrm{a}}$ & 0.008 & $9.48565^{\mathrm{a}}$ & 5.326 \\
\hline \multicolumn{8}{|l|}{ Muscularity of dam } \\
\hline Class 2 & 414 & $214.65^{\mathrm{b}}$ & 2.04 & $0.968^{\mathrm{b}}$ & 0.012 & $9.38785^{a}$ & 7.36 \\
\hline Class 1 & 384 & $218.69^{b}$ & 2.11 & $0.975^{\mathrm{b}}$ & 0.012 & $9.24367^{a}$ & 7.61 \\
\hline Class 0 & 3,031 & $220.69^{a}$ & 1.11 & $0.985^{\mathrm{a}}$ & 0.006 & $9.19467^{\mathrm{a}}$ & 3.99 \\
\hline
\end{tabular}

Unequal letters express raw means significantly different for $\mathrm{P}<0.05$. 
Male calves are heavier at weaning and grow faster than females (NELSEN and KRESS, 1981). In our breed average WW and ADG for males are 8\% superior than for females (Table 3). It can characterise a higher growth ability for males. However, we can not reject the influence of a possible differential treatment between males and females because of the non-experimental origin of our data.

As previously described in the literature (ELZO et al., 1987; NELSEN and KRESS, 1981) WW and ADG increases with calving number till fourth calving as a consequence of the differences in nursing ability between developing and adult dams (Table 3). In Asturiana de los Valles breed the offspring of adult dams perform around $225 \mathrm{Kg}$ and $1.010 \mathrm{Kg} /$ day for WW and ADG respectively.

The degree of muscularity of the calf and dam do not influence significantly ADG (Table 2). Double muscled calves are heavier and have a lower RGR than class 1 and class 0 calves (Table 3).

Table 4 shows the regression coefficients for the age at weaning as linear and quadratic covariates. Even thought ADG and RGR show non-linear behaviour with respect to the age at weaning, WW is only influenced significantly by the linear covariate. This linear behaviour of WW was not expected taking into account the range of age at weaning we consider in this study. Preweaning ADG decreases with age. In the range of age of our data this should affect WW (WOODWARD et al., 1989). However, the age at weaning affects specially to RGR. For this trait, the linear covariate explains the $37.6 \%$ of the total sum of squares and the quadratic covariate the $1.6 \%$ (Table 2). The behaviour of RGR with respect to the age at weaning characterises the decrease of ADG with respect to starting weight (birth weight) that remains constant.

Table 4

Figures and signification of the regression coefficients for the age at weaning as linear and quadratic covariates for three preweaning growth traits in Asturiana de los Valles beef cattle breed (Regression für das Absetzalter und lineare und quadratische Kovarianzen für untersuchte Merkmale)

\begin{tabular}{llll}
\hline Age at weaning & Actual weaning weight & Average daily gain & Relative growth rate \\
\hline Linear & $0.6901265^{* * *}$ & $-0.0016643686^{* * *}$ & $-0.00000354376^{* * *}$ \\
Quadratic & -0.0004067 & $0.00000056655^{* * *}$ & $0.0000001334^{* * *}$
\end{tabular}

*** express significance for $\mathrm{P}<0.001$.

Table 5

Genetic parameter values and standard errors (below) affecting for three preweaning growth traits in Asturiana de los Valles beef cattle breed (Genetische Parameter und Schätzfehler (unten) der untersuchten Merkmale)

\begin{tabular}{lllcccc}
\hline & $\mathrm{h}^{2}$ & $\mathrm{~m}^{2}$ & $\mathrm{r}_{\mathrm{am}}$ & $\sigma_{\mathrm{am}} / \sigma^{2}$ & $\mathrm{~h}_{\mathrm{T}}^{2}$ \\
\hline Actual weaning weight & 0.67 & 0.29 & -0.76 & -0.34 & 0.31 \\
Average daily gain & 0.10 & 0.11 & & 0.12 & 0.17 \\
& 0.51 & 0.31 & -0.82 & -0.33 & 0.09 & \\
Relative growth rate & 0.07 & 0.08 & & -0.06 & 0.15 \\
& 0.18 & 0.12 & -0.43 & 0.06 & \\
\hline
\end{tabular}

\section{Genetic Parameters}

Genetic parameters affecting our traits are presented in Table $5 \mathrm{WW}$ and ADG show high heritabilities for direct effect ( 0.67 and 0.51 respectively) and a moderate maternal effect ( 0.29 and 0.31 respectively) with a very high and negative genetic correlation 
between both parameters. However, RGR shows moderate heritabilies for both direct and maternal (0.18 and 0.12). Genetic correlation between direct and maternal effects for RGR was also negative but lower than in the other traits. Total heritability (DICKERSON, 1947) was 0.31, 0.17 and 0.15 for WW, ADG and RGR, respectively.

\section{Discussion}

Major environmental factors affect preweaning growth performance of Asturiana de los Valles calves in the direction usually found in the literature. Under a traditional production system the growth ability of the calves is affected by a lesser nursing ability of the mother in the last months of the lactating period within the dry season that can not be balanced by the calf by increasing the grass intake (WRIGHT and RUSSEL, 1987).

As reported before by AHUNU and MAKARECHIAN (1987) the sex of calf and the calving number of the dam influence significantly preweaning growth traits except for RGR (Table 2). However the raw means of RGR by sex of calf show significant differences. RGR characterises the ADG by starting weight unit (FITZHUGH and TAYLOR, 1971). In consequence RGR tends to be higher in animals with lower birth weights (GREGORY et al., 1978), such as in females. As shown in previous analysis (GOYACHE et al., 2000) birth weight increases significantly with calving number until fifth calving. The definition of RGR can recover all the variation of growth ability dependent on the age of the age of dam and calf sex.

Literature reports that double muscled calves show a higher growth ability in preweaning ages (MENISSIER, 1982). This has been stated both in experimental condition (VALLS ORTIZ et al., 1972) and using field data (GOYACHE et al., 2002). Classifications of muscularity we use here try to characterise expected to characterise in some extent the influence of muscular hypertrophy. Since double muscled calves are heavier at birth (MENISSIER, 1982; GOYACHE et al., 2002) and taking into account that RGR tends to be higher in animals with lower birth weights (GREGORY et al., 1978), the results reflected in Table 2 and 3 agree with the expected. On the other hand, the offspring of poorer muscled (class 0) dams are heavier, grow faster and have lower RGR than the other dam's offspring (Table 3). We have reported previously that in Asturiana de los Valles breed phenotypically normal dams (class 0 ) produce, on average, calves $2.2 \mathrm{~kg}$ heavier at birth than double muscled dams (class 2) (GOYACHE et al., 2000) regardless the muscularity of the calf. In addition, normal dams produce more milk than muscled dams (MENISSIER, 1982) This would lead to higher ADGs (at least $10 \mathrm{~g}$ /day higher as shown in Table 3) for the offspring of our class 0 dams. However, this higher growth rate can not compensate the higher average birth weight found for the normal dams in our breed giving lower mean RGR.

\section{Genetic Parameters}

The figures reported in the present work for genetic parameters affecting preweaning growth traits are consistent but slightly higher than others reported before in our breed for WW and ADG (GUTIERREZ et al., 1997). Genetic parameters for RGR were estimated for the first time in the Asturiana de los Valles breed. Our results are in general, higher than those usually observed in the literature. MOHIUDDIN et al. (1993) weighting various published estimates by the number of records used in each analysis obtained average values for WW of 0.22 for the direct genetic effect, 0.13 for the maternal genetic 
effect and -0.15 for the genetic correlation between these parameters. KOOTS et al. (1994a) weighting various published estimates by the inverse of their sampling variance, obtained mean heritabilities of the direct effect of $0.24,0.296$ and 0.22 for WW, ADG and RGR, respectively. These average estimates for the maternal genetic effect were 0.13 and 0.25 for WW and ADG respectively. In our study, the genetic correlations estimated between direct and maternal genetic effects for WW and ADG are more negative than those usually found in the literature. KOOTS et al. (1994b) averaging published estimates of genetic correlations between direct and maternal genetic effects (23 for WW and 9 for ADG) report negative but moderate average values of -0.25 and -0.30 respectively. There is no available estimation of genetic parameters of RGR involving maternal genetic effects. JOHNSTON et al. (1992), in Canadian Charolais cattle, found a heritability for the direct genetic effect of 0.18 under a sire model.

There is a general agreement about the deficiencies of the models involving maternal genetic effects. The estimations of direct and maternal genetic effects tend to be imprecise due to large sampling correlations between parameters (MEYER, 1997). However, genetic correlations between direct and maternal genetic effects estimated in populations showing a correct structure of data are still negative (SHI et al., 1993; SWALVE, 1994). When the covariance between direct and maternal genetic components is not negligible, the genetic effects estimated under an animal model, are forced to be higher by the action of inflated negative correlation between both genetic components (GUTIÉRREZ et al., 1997; MEYER, 1997). Some causes, such as unaccounted differences in management within contemporary groups (MEYER, 1997; BERWEGER BASCHNAGEL et al., 1999) or deficiencies in identification of the animals (LEE and POLLACK, 1997) can be in the basis of these inflated estimations. ROBINSON (1996a, b) on simulated data and BERWEGER-BASCHNAGEL et al. (1999) on field data suggested a possible confusion between environmental and genetic effects linked to sire resulting in an overestimation of the additive genetic variance.

RGR differs from the other traits. Despite the structure of data is the same than in classical preweaning growth traits, the genetic correlations between direct and maternal genetic effect is less negative leading to lower estimates of the heritability for both the direct and maternal genetic effects. There is little scientific information on RGR. This trait seems to be self-corrected for the major environmental factors affecting preweaning growth traits in cattle, such as sex of calf and calving number of the dam. This better adjustment of environmental factors can be in the basis of the estimation of more realistic genetic parameters for this trait than for the classical WW and ADG. Since selection for RGR would lead to obtain higher growth rates and lower birth weights this trait could be an interesting breeding goal in beef cattle to improve ADG without increasing birth weights and calving problems. Further research is needed to estimate genetic correlations between RGR and other productive and reproductive economically important traits in beef cattle.

\section{Acknowledgements}

This paper has been partially supported by a grant from MCyT-FEDER, no 1FD97-1633 and from the Regional Government of the Principado de Asturias through Consejería de Medio Rural y Pesca. Authors would like to thank S. SIDLER for his kind help and comments. 


\section{References}

AHUNU, B.; MAKARECHIAN, M.:

Preweaning patterns of growth in the three breed groups of range beef calves. Can. J. Anim. Sci., Otawa, 67 (1987), 653-661

BERWEGER BASCHNAGEL, M.; MOLL, J.; KUNZI, M.:

Comparison of models to estimate maternal effects for weaning weight of Swiss Angus cattle fitting a sire $\mathrm{x}$ herd interaction as an additional random effect. Livest. Prod. Sci., Shannon, 60 (1999), 203-208

DICKERSON, G.E.:

Composition of hog carcasses as influenced heritable differences in rate and economy of gain. Iowa Agric. Exp. Sta. Res. Bull, 354 (1947), 489-524

ELZO, M.A.; QUASS, R.L.; POLLAK, E.J.:

Effects of age of dam on weight traits in the Simmental population. J. Anim. Sci., Savoy, 64 (1987), 9921001

GOYACHE, F.; GUTIERREZ., J.P.:

Heritability of reproductive traits in Asturiana de los Valles beef cattle breed. Arch. Anim. Breed., Dummerstorf 44 (2001), 489-496

GOYACHE, F.; GUTIÉRREZ, J.P., FERNÁNDEZ, I.; VILLA, A.; ALVAREZ, I.; RODRÍGUEZ CASTAÑÓN, A.A.; GARCÍA PALOMA, J.A.:

Efectos ambientales que influyen en la dificultad de partos y el peso al nacimiento en la raza Asturiana de los Valles. Arch. Zootec., Córdoba 49 (2000), 481-492

GOYACHE, F.; ROYO, L.J.; ALVAREZ, I.; GUTIÉRREZ., J.P.:

Testing a continuous variation in preweaning expression of muscular hypertrophy in beef cattle using field data. Arch. Anim. Breed., Dummerstorf 45 (2002), 139-149

GREGORY, K.E.; CUNDIFF, L.V.; SMITH, G.S.; LASTER, D.B.; FITZHUGH, H.A.JR.:

Characterization of biological types of cattle - cycle II: 1. Birth and weaning weights. J Anim Sci., Savoy, 47 (1978), 1022-1030

GUTIÉRREZ, J.P.; CAÑÓN, J.; GOYACHE, F.:

Estimation of direct and maternal genetic parameters for preweaning traits in the Asturiana de los Valles beef cattle breed through animal and sire models. J. Anim. Breed. Genet., 114 (1997), 261-266

FITZHUGH, H.A.JR.;TAYLOR, ST.C.S.:

Genetic analysis of degree of maturity. J Anim Sci., Savoy, 33 (1971), 717-725

JOHNSTON, D.J.; BENYSHECK, L.L.; BERTRAND, J.K.; JOHNSON, M.H.: WEISS, G.M.:

Estimates of genetic parameters for growth and carcass traits in Charolais cattle. Can. J. Anim. Sci., Otawa, 72 (1992), 493-499

KOOTS, K.R.; GIBSON, J.P.; SMITH, C.; WILTON, J.W.:

Analyses of published genetic parameter estimates for beef production traits. 1. Heritability. Anim. Breed. Abstr. 62 (1994a), 309-338

KOOTS, K.R.; GIBSON, J.P.; WILTON, J.W.:

Analyses of published genetic parameter estimates for beef production traits. 2. Phenotypic and genetic correlations. Anim. Breed. Abstr. 62 (1994b), 825-853

LEE, C.; POLLACK, E.J.:

Influence of sire misidentification on sire $\mathrm{X}$ year interaction variance and direct-maternal genetic covariance for weaning weight in beef cattle. J. Anim. Sci., Savoy, 75 (1997), 2858-2863

MENISSIER, F.:

Present state of knowledge about the genetic determination of muscular hypertrophy or the double muscle trait in cattle. In: KING J.W.B.; MENISSIER F. (Eds.), Muscular Hypertrophy of Genetic Origin and its MEYER, K.: Use to Improve Beef Production. Curr. Top. Vet. Anim. Sci., Amsterdam, 16 (1982), 387-428

MEYER, K.:

Estimating variances and covariances for multivariate Animal Models by Restricted Maximum Likelihood. Genet. Sel. Evol., Les Ulis, 23 (1991), 67-83

Estimates of genetic parameters for weaning weight of beef cattle accounting for direct-maternal environmental covariances. Livest. Prod. Sci., Shannon, 52 (1997), 187-199

MOHIUDDIN, G.:

Estimates of genetic parameters of some performance traits in beef cattle. Anim Breed Abstr, 61 (1993), 495-522

NELSEN, T.C.; KRESS, D.D.:

Additive and multiplicative correction factors for sex and age of dam in beef cattle weaning weight. J.

Anim. Sci., Savoy, 53 (1981), 1217-1224

ROBINSON, D.L.: 
Estimation and interpretation of direct and maternal genetic parameters for weights of Australian Angus cattle. Livest. Prod. Sci., Shannon, 45 (1996A), 1-11

ROBINSON, D.L.:

Models which might explain negative correlations between direct and maternal genetic effects. Livest. Prod. Sci., Shannon, 45 (1996B), 111-122

SAS INSTITUTE INC.:

SAS user's guide: Statisticsed SAS Institute, Inc, Cary, NC, USA (1999).

SHI, M.J.; LALOÈ, D.; MENISSIER, F.; RENAND, G.:

Estimation of genetic parameters of preweaning performance in the French Limousin cattle breed. Genet. Sel. Evol., Les Ulis, 25 (1993), 177-189

SWALVE, H.H.:

Estimation of direct and maternal (co)variance components for growth traits in Australian Simmental beef cattle. J. Anim. Breed. Genet., 110 (1993), 241-252

VALLS ORTIZ, J.M.; MENISSIER, F.; VISSAC, B.:

Etude du caractère culard. VI. Transmission et posibilités d'utilisationen croisement de prèmiere génération pour la production de veaux de boucherie. Ann. Génét. Sel. Anim., 4 (1972), 7-28

WOODWARD, B.W.; POLLAK, E.J.; QUAAS, R.L.:

Adjusting weaning weights of simmental beef calves to an age constant basis. J. Anim. Sci., Savoy, 67 (1989), 20-27

WRIGHT, I.A.; RUSSEL, A.J.F.:

The effect of sward height on beef cow performance and the relationship between calf milk and herbage intake. Anim. Prod., Midlothian, 45 (1987), 423-432

Received: 2002-10-22

Accepted: 2003-05-06

Author's addresses

FELIX GOYACHE*, PhD; I. FERNÁNDEZ, LUIS .J. ROYO,

ISABEL ALVAREZ,

SERIDA-CENSYRA-Somió

Área de Genética y reproducción Animal

C/ Camino de los Claveles 604,

E-33203 Gijón (Asturias), Spain

E-Mail: fgoyache@serida.org

JUAN P. GUTIERREZ, PhD

Dpto. de Produccion Animal

Facultad de Veterinaria

Universidad Complutense de Madrid

E-28040 Madrid, Spain 